\title{
ENGLISH CONTAINER METAPHORS OF EMOTIONS IN UKRAINIAN TRANSLATIONS
}

\author{
Liudmyla Kovalenko, \\ V.N. Karazin Kharkiv National University, Kharkiv, Ukraine \\ lucydoro1@gmail.com
}

\author{
Alla Martynyuk \\ V.N. Karazin Kharkiv National University, Kharkiv, Ukraine \\ allamartynyuk@ukr.net
}

\begin{abstract}
This study presents the results of comparative analysis of linguistic instantiations of English CONTAINER metaphors of emotions and their Ukrainian translations to reveal the cognitive models and cognitive operations that underpin the translations. The research data includes 2,000 utterances with CONTAINER metaphors of emotional states that come from G. Martin's novels and their translations into Ukrainian performed by V. Brodovyj. Ukrainian translations of the English EMOTION as CONTAINER mapping are based on three cognitive operations: reconstruction, substitution and elimination. There are some structural differences in linguistic instantiations of the EMOTION as CONTAINER mapping in the original and translation stemming from the analytical nature of English and synthetic nature of Ukrainian. If English CONTAINER metaphors are verbalised predominantly syntactically, by prepositional phrases, Ukrainian CONTAINER metaphors are verbalised mostly morphologically, by derivative words with the prefixes, etymologically connected to the idea of a CONTAINER. As for semantic differences, in Ukrainian translations EMOTIONS-BOUNDARIES mappings tend to be substituted with EMOTIONS-INTERIORS mappings. It implies an inference that Ukrainians imagine EMOTIONAL STATES as SUBSTANCES filling the insides of their bodies rather than BOUNDARIES suppressing them from the outside. Another tendency is substituting the CONTAINER as a STATIC PASSIVE ENTITY with some ACTIVE AGENT like a HUMAN / LIVING BEING influencing the EXPERIENCER.
\end{abstract}

Keywords: cognitive operation; emotion; image schema; metaphor; translation.

\section{Introduction}

The primary objective of this paper is to compare English CONTAINER metaphors of emotions and their Ukrainian translations and reveal the cognitive models and cognitive operations that underpin these translations.

Though, since publishing Lakoff and Johnson's seminal paper "Metaphors we live by" (1980) a cognitive metaphor has become one of the most popular objects of cognitive linguistics research - to name just some of the most influential works (Fauconnier, 2002; Gibbs, 2011; Gibbs \& Colston, 2012; Grady, 1999; Johnson, 1987; Kövecses, 2017; Lakoff, 1987, 1990, 1993; Lakoff \& Johnson, 1999; Lakoff \& Turner, 1989) - up to now, far too little attention has been paid to metaphors in discourse (Musolff, 2016; Semino, 2008) and there are practically no papers in translation studies focused on the cognitive models / operations licensing the choice of linguistic instantiations of conceptual metaphors in translations. This research aims at narrowing this gap.

The research data includes 2,000 English utterances with CONTAINER metaphors of emotions and their Ukrainian translations. The utterances come from G. Martin's best-seller novels and their translations into Ukrainian performed by V. Brodovyj.

The database is seen as a product of interaction, though disconnected in time, between the writer and translator, where situated metaphorical mappings verbalised by a representative of Anglo-American linguoculture are unpacked and re-mapped and verbalised by a representative of Ukrainian linguoculture.

This approach re-orients the database of cross-linguistic metaphor research from the abstract linguistic units taken from different sources (mostly dictionaries, and/or Corpus texts) and, consequently, different contexts, towards the study of situated construal of metaphorical meanings.

\section{Theoretical prerequisites}

In the recent development of the conceptual metaphor theory, "the multi-level view of metaphor", suggested by Kövecses (2017), conceptual metaphor is seen as a result of mappings between the source and target conceptual structures of four levels of schematicity (following Langacker (1987, p. 492), schematicity is addressed as "relative precision of specification along one or more parameters"): the level of image schemas, the level of domains, the level of frames, and the level of mental spaces, "the highest level being that of image schemas and the lowest that of mental spaces, with domains and frames in between" (Kövecses, 2017, pp. 343-344). The scholar suggests that "the lower levels are more specific versions of the 
higher, more schematic levels" (ibid., p. 344). A similar approach is discussed in (Dancygier \& Sweetser, 2014) under the rubric of "levels of schematicity"; see also (Dancygier, 2016).

One important division characterising this schematic hierarchy is the distinction between image schemas as analogue structures and frames / domains / mental spaces as non-analogue (propositional) structures. The other division is between levels that belong to long-term memory (image schemas / domains / frames) and the level of mental spaces that function online in working memory (Kövecses, 2017).

In keeping with Lakoff (1987) and Johnson (1987), image schemas are described as directly meaningful preconceptual structures, highly schematic gestalts, continuous analogue patterns, internally structured, consisting of only a few parts (Hampe, 2005, pp. 1-2), and exemplified by CONTAINER, VERTICALITY, and (STRUCTURED) OBJECT. Domain is defined after Langacker (1987), as "a coherent area of conceptualisation relative to which semantic units may be characterized" and described as having many more parts than an image schema, and thus being more information-rich (p. 488). Domains are structured by image-schemas. For instance, the BODY and BUILDING domains are based on the CONTAINER, VERTICALITY, and (STRUCTURED) OBJECT image schemas. Frames are understood in Fillmore's (1982) spirit and addressed as less schematic conceptual structures than domains, elaborating particular aspects of a domain matrix. Siding with Sullivan (2013), Kövecses describes this relationship as inclusion: domains include / consist of frames. In his example, the BODY domain is elaborated by several distinct frames, such as PERCEPTION, INGESTION, and EXERCISING. Mental spaces are seen as "small conceptual packets constructed as we think and talk for purposes of local understanding and action" (Fauconnier \& Turner, 2002, p. 102). Kövecses underlines that mental spaces function at a very specific and conceptually rich level: unlike frames mental spaces "do not operate with generic roles and relations in most cases but with specific instances of roles and relations" (2017, p. 326).

As it follows from the original Fauconnier and Turner (2002) definition, unlike other cognitive structures mental spaces are action-oriented. This detail reminds us that metal spaces function in real interaction where our mental experience, involved in generation of meaning, is being affected by our interests, wishes, needs, and feelings shaping our motives and goals because we use it (consciously or unconsciously) to inform our communicative actions in reaching our communicative and - through them social goals in a specific sociocultural context (Martynyuk, 2017, pp. 64-65).

Kövecses (2017) underlines these issues saying that individual speakers mobilise, manipulate and modify their decontextualised, static, and routine conceptual structures in real-world metaphorical conceptualisation in information-rich contexts in order to achieve particular goals (social, expressive, rhetorical, etc.) (2017, p. 341). What he does not accentuate, is the creative aspect of mental spaces which involves deriving novel inferences - emergent structures. The notion of a new inference, mentioned by Kövecses (2017) in line with other properties of mental spaces, prompts the idea that generation of meaning is a far more complicated process than mapping between the source and target conceptual structures of different levels of schematicity.

Kövecses's proposal does not shed light on the nature of inference or its role in metaphorical mapping, and broader - in generation of meaning. Should we assume that metaphorical mappings are automatically recruited in thought and verbalised in speech or should we treat them as inferential cognitive operations exploiting non-operational static pre-existing cognitive structures (image schemas, frames / domains), as Ruiz De Mendoza and Galera (2014) do? And if metaphorical mappings are inferential operations, should we regard them as part of rational reasoning since inference is typically treated as a rational structure / process? In this latter case, should image schemas be excluded from the cognitive operations inventory, since, "it is usually taken for granted that only propositional structures are used in reason and that anything imagistic in character is not used in reasoning" (Lakoff, 1987, p. 459)?

An answer to the last question is prompted by Lakoff (1987) himself who admits that "we are not even close to knowing what kind of image schemas are used in cognition and what kind of reasoning can be done with them" and qualifies the perspective of discovering this as exciting since "it would provide an account how knowledge gained from perception and knowledge gained from language can function together in reasoning" (p.459).

It seems such a possibility opens if we look at reasoning through the framework of advanced cognitive theories which go beyond propositional structures and take into account sensations, affect, intuition, insight, and free will as they interweave in the mind-body interactions with the environment.

A good example of such theories is Hardy's synergistic theory of semantic constellations (1998) which represents "the whole mind-psyche of an individual" as a dynamical and self-organising semantic lattice, i.e. transversal mental-neural network (p. 17), involving two-way mind-body interactions and housing "all of a 
person's knowledge, sensoriality, affectivity, and behavior patterns - both as memory clusters and as a living, growing experience" (p. 18).

Semantic constellations are units of our mental life (Hardy, 1998, p. 14); they "are far more than just "belief-sets" or "declarative knowledge-sets" (p. 4). Rather, they are "dynamical and evolving networks of meanings and related processes, organised around a nucleus. The nucleus, the central meaning, ties together interrelated concepts, internal sensations, images, sounds, colours, gestures, acts, attitudes, behaviors, moods, and so forth" (p. 14), while the semantic constellation is "the ensemble, the network implicating all these various elements" (p. 14).

Clusters of semantic elements are attracted to and link themselves to other semantically related clusters in low-level connective dynamic, i.e. the spontaneous linkage process, based upon a wide variety of connections such as contiguity, metaphor, analogy, contradiction, differentiation, sets and subsets, and more (Hardy, 1998, p. 6).

From a perspective opened by this theory, "conscious thought is the end product of the internal connective processes at work in the whole network and its constant dynamical self-organization" (Hardy, 1998, p. 29).

Put in this framework an inference is viewed as a natural product of the global process of generating meaning: a contextually motivated action-oriented semantic structure that is activated by a linguistic expression as a perceptual stimulus and is a product of complex parallel conscious and unconscious multilevel processes involving two-way mind-body interactions and recruiting the multi-level sensory, cognitive, volitional and affective structures of experience gained in the exchanges of the subjects with their environment (Martynyuk, 2017, p. 67).

Though inferences are basically treated as rational structures / processes underpinning logical reasoning, in view of the complexity of the interplay of the rational, volitional and emotional, conscious and unconscious in generating meaning it seems plausible to speak of:

1) rational inferences - made by high-level logical reasoning;

2) emotional inferences - prompted by low-level dynamics of sensations, positive / negative affective states, feelings, and attitudes;

3) volitional inferences - based on self-reflection / self-awareness and presupposing a free-will choice;

4) heuristic (unconscious) inferences - fed by implicit knowledge and intuition (the term "unconscious inference" belongs to Helmholtz (1925) who defined it as a product of visual perception, needed for guiding all actions of our self in the world).

On the other hand, it seems necessary to draw the line between classifying / qualifying inferences and behavioural inferences (this idea was earlier proposed in Martynyuk, 2016).

Classifying / qualifying inferences (What am I dealing with? Is it good or bad for me?) are based on declarative knowledge (i.e. conscious precise memories and recognition of objects and events as expressed through language (Anderson, 1976))

Behavioural inferences (How am I to deal with it for my benefit?) rely on both declarative and procedural knowledge (i.e. implicit memory of psychomotor processes as procedures that have become automatic and nonconscious (Anderson, 1976)).

These assumptions reconcile inferential nature of metaphorical mappings with the nonlinear logic of metaphor processing that involves analogue structures, does not follow fixed rules and presupposes "true qualitative leaps and abrupt shifts in reasoning" (Hardy, 1998, p. 25), when the results of unconscious processing emerge as insights. Besides, these assumptions help account not only for conventional metaphors as systematic associations, instantiated in conventional linguistic expressions but also for unique original metaphors - products of insights. On top of that, they also embrace affect and emotion encoded in metaphors and actualised as "pragmatic effects" which these metaphors produce in communication and ignoring which is recognised as "a major debt of conceptual metaphor theory" (Kövecses, 2017, p. 345); see (Semino, 2008).

Interpreted from this perspective, mental spaces transform abstract schematic hierarchy of multi-level metaphor into a working model of creating linguistic meaning. Representing individual live experience of the interlocutors (cognitive (rational thought), affective (feelings, emotions, attitudes), volitional (needs, wants, interests, shaping their communicative goals)), mental spaces naturally recruit their sociocultural experience shaped by domains/frames which in turn are structured by image schemas representing their "supraindividual" universal bodily experience. And what is even more important, mental spaces adjust this experience for the immediate purposes of interaction in a specific sociocultural and interactive context.

Thus, in this study a metaphorical mapping is seen as an inferential (in the synergetic sense given above) cognitive operation of conscious / unconscious - rational / emotional nature that structures abstract cognitive experience in terms of more concrete cognitive / emotional / sensory-motor experience, organised 
in analogue and propositional cognitive structures (cognitive models) of different degree of schematicity and instantiated in conventional and original linguistic expressions.

Going back to the object of analysis - English CONTAINER metaphors of emotions and their Ukrainian translations - it seems appropriate to describe the translations as products of interaction (though disconnected in time) between the Anglo-American writer and the Ukrainian translator when the latter focuses attention on a contextual CONTAINER metaphor, created by the former, as a perceptual stimulus which triggers parallel conscious / unconscious inference processes involving cognition, volition, and affect to evoke / create an interpretive cognitive structure - a metaphorical mapping - which is verbalised in translation. Naturally, such products will be shaped by rational reasoning as much as by intuition and insight since translation is a creative process (Rebrii, 2012), and they will be heavily influenced by the translator's specific cultural experience, by the awareness of the differences between the cultures and also by the restrictions imposed on the translator by the structures of the original and translation languages.

\section{Methodology}

Being a natural product of a working mind, an inference appears to be an efficient instrument of cognitive analysis of communication, intentionally applied by a linguist to discover not only rational but also affective and volitional aspects of experience influencing the generation of linguistic meanings in specific contexts; see cases of such analysis in (Martynyuk, 2017). And inferential analysis is applied in this study to analyse the Ukrainian mappings of the English CONTAINER metaphors of emotions.

As it has been said, metaphorical mappings analysed in this study are based on the CONTAINER image schema. An image schema is understood as a mental representation or a cognitive model, i.e. a pre-existing cognitive structure, which, as specified by Johnson, is "a recurring, dynamic pattern of our perceptual interactions and motor programmes that gives coherence and structure to our experience" (1987, p. xiv).

It is assumed that image schemas structure our bodily experience (Lakoff, 1987, p. 453; Johnson, 1987, p. 29), being not specific to a particular sensory modality (Lakoff, 1987, p. 267; Johnson, 1987, pp. 24-25), and they also structure our non-bodily experience through metaphorical mappings (Lakoff, 1987, p. 453; Johnson, 1987, p. 29); see (Cienki, 2013).

Image schemas are seen as cognitive models engaged in cognitive operations, i.e. "mechanisms that our minds use in order to store and retrieve information and also to make mental representations" (Ruiz De Mendoza \& Galera, 2014, p. 85). While image schemas are ways of organising knowledge arising from our interaction with the world, cognitive operations are a matter of re-construal or re-interpretation of the organised knowledge by mapping conceptual structure in different ways. In the case of metaphor, the source domain is used to reason about the target domain (pp. 2-3). This cognitive operation results in creating a new cognitive model, a metaphorical one.

In Kövecses's view (2017) image schemas are primary cognitive models since they are directly grounded in our sensory experience. Other recent studies suggest that image schemas are themselves complex structures operating at more than one level of conceptualisation (Mandler \& Cánovas, 2014), which gives more importance to their role in the emergence of complex meanings (Dancygier, 2016, p. 36).

The idea behind the EMOTION as CONTAINER metaphorical mapping is that a meaningful structure from bodily experience gives rise to more concrete concepts like the CONTAINER image schema, which in turn serve to structure more abstract conceptual domains like EMOTIONAL STATES.

Anyway, the CONTAINER image schema consists of the structural elements: INTERIOR, BOUNDARY and EXTERIOR. These are the minimum requirements for a CONTAINER (Fig. 1).

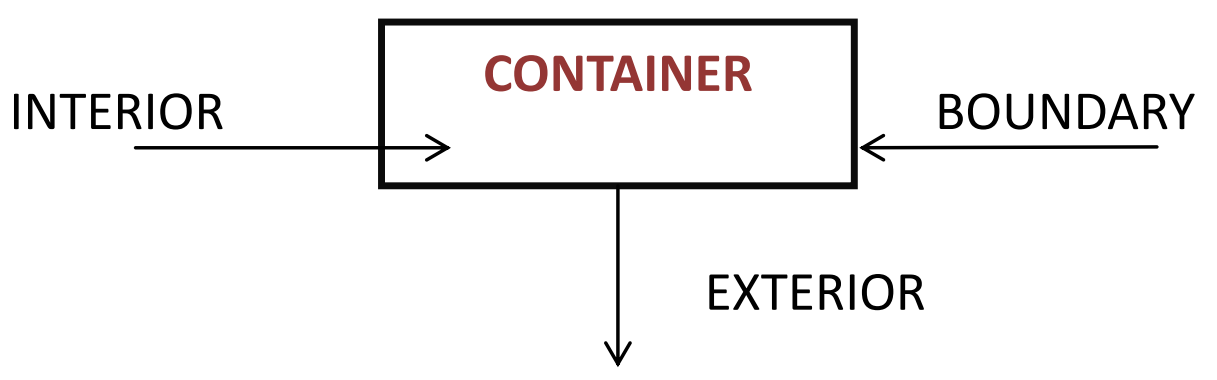

Fig.1. CONTAINER image schema

The BOUNDARY and the EXTERIOR together possess sufficient gestalt properties (e.g., closure and continuity) to make CONTAINER the figure, while the EXTERIOR is the ground (Lakoff, 1987). 
The inferential analysis shows that CONTAINER metaphorical mappings work on two basic cognitive models: EMOTIONS as BOUNDARIES of CONTAINERS for EXPERIENCES (He is in love) and EMOTIONS as INTERIORS of CONTAINERS-EXPERIENCERS (She is full of disgust).

So the first step in handling the data involves revealing the basic cognitive models underpinning the Anglo-American CONTAINER metaphors of emotions and classifying them on these grounds.

The second step presupposes considering linguistic instantiations of these metaphorical models in terms of their syntactic / morphological and lexical properties.

The third step aims at revealing specifications of the CONTAINER image schema. Such specifications can result from the cognitive operations of elaboration or extension (Lakoff \& Turner, 1989, pp. 67-68). An extension is observed when a new aspect of the BOUNDARY is highlighted, e.g., colour: He was in a red rage. Elaboration takes place when generic concepts like the BOUNDARY or INTERIOR are specified in a non-conventional way, e.g., in His anger spilled out the INTERIOR of CONTAINER-EXPERIENCER is specified as UNCONTROLLED LIQUID.

The fourth step is discovering cognitive models underpinning the Ukrainian translations of the AngloAmerican metaphors and their linguistic instantiations. Taking into consideration different grammatical structure of analytical English and synthetic Ukrainian it is relevant to presuppose that Ukrainian translations will demonstrate more specifications, elaborating or extending the two basic CONTAINER models, and also different metaphorical models going beyond the CONTAINER image schema. It also seems plausible to predict that in some cases Anglo-American metaphors will be lost in Ukrainian translations.

The fifth step lies in comparing cognitive models used in the Anglo-American and Ukrainian metaphorical mappings and revealing cognitive operations licensing the Ukrainian mappings in terms of reconstruction of the metaphorical model (the original and translation are licenced by the same cognitive model or its specification), substitution of the metaphorical model (the original metaphorical model is substituted by another metaphorical model in the translation) or elimination of the metaphorical model (the original metaphorical model is lost in the translation).

\section{Results and discussion}

The inferential analysis reveals that in the Anglo-American fiction EMOTIONAL STATES, mapped in terms of the CONTAINER image schema, are conceived either as INTERIORS of CONTAINERSEXPERIENCERS $(40,60 \%)$ or as BOUNDARIES of CONTAINERS for EXPERIENCERS $(59,40 \%)$. Quantitative analysis shows that EMOTIONS are more often seen as BOUNDARIES of CONTAINERS for EXPERIENCERS.

English EMOTION-BOUNDARY mappings licence conventional metaphors which are expressed:

1) lexically-syntactically, by free phrases with the prepositions in/out of, e.g., in dismay / out of love;

2) lexically-morphologically, with the help of the prefix en-from the French in-, meaning "inside" used to coin verbs from nouns and adjectives meaning "to put into" (Brown, 1993), like in enraptured.

Conceptually, English EMOTION-BOUNDARY mappings have extensions highlighting the temperature or colour of the CONTAINER:

Eddard Stark had ridden out that very day in a cold rage, to fight the last battles of the war alone in the south (Martin, 1996);

Calling him Snow reminded him of his bastardy and sent him into a black rage (Martin, 2011).

Besides, EMOTIONS-BOUNDARIES have elaborations specifying CONTAINERS as:

WATER / POOL / RIVER / SEA: Can you drown in grief? (Martin, 1999);

LIGHT: Anger flashed across Father's face (Martin, 1996).

As for EMOTIONS-INTERIORS, linguistically such mappings are expressed:

1) lexically-syntactically, by the:

a) free phrases with the prepositions in (anger in his eyes), within (dread within her), inside (the rage inside him), out of (to keep the scorn out of his voice), out (blurted out his fears) locating EMOTION in/out of the (part of) body of the EXPERIENCER;

b) verb to fill (Fear filled his gut) which, functioning as a predicate, relates the AGENT-EMOTION and the UNDERGOER-EXPERIENCER;

c) set adjectival phrases full of, filled with / empty of (full of melancholy / empty of expression);

2) lexically-morphologically, by the suffix ful- (fretful, scornful, fearful) used to form adjectives from nouns with the sense "full of or having" (Brown, 1993).

Conceptually, English EMOTIONS-INTERIORS metaphors are elaborated as:

LIQUIDS: Jaime's anger had risen up in his throat (Martin, 1996);

LIGHT: Fury shone from his lilac eyes (Martin, 1996); 
FIRE: Worry burned in their hearts (Martin, 1996);

LIVING BEINGS: She could feel the fear in her tummy, twisting and pinching, worse every day (Martin, 1996);

OBJECTS: Something had put a fear in him so deep that my words could not reach him (Martin, 1996);

WEAPONS: When she spied the manticore crawling across the shield of their leader, a stab of hate shot through her (Martin, 1999);

PLANTS: Joy bloomed in her heart (Martin, 1999);

FOOD: Fear filled his gut like a meal he could not digest (Martin, 1996);

POISON: They [eyes] were full of poison (Martin, 1996).

Before we move on to the analysis of the Ukrainian translations, we would like to draw attention to the fact that in linguistic descriptions English CONTAINER metaphors are tightly linked with prepositions and consequently described as analytical units, their synthetic instantiations being overlooked.

Inferential analysis of the Ukrainian translations of the EMOTION-BOUNDARY metaphors shows that this metaphorical model is mostly reconstructed $(59,40 \%)$, though it can be substituted $(29,50 \%)$ by a different model or lost $(11,10 \%)$.

In most cases the EMOTION-BOUNDARY model is reconstructed by analytical means: free phrases with prepositions $\boldsymbol{y} / \boldsymbol{b}$ which are direct translation equivalents of $\boldsymbol{i n}$ :

Littlefinger groaned in dismay (Martin, 1996) - Мізинець застогнав у відиаї (Martin, 2015b).

An interesting and rare case is represented by an analytical Ukrainian translation (expressed by a free prepositional phrase) of a synthetic English metaphor expressed by a derivative adjective with the prefix $\boldsymbol{e n - :}$

Drogo will be enraptured (Martin, 1996) - Дрого буде y зaxвami (Martin, 2015b).

Much more typical is a reverse case when an analytical English metaphorical phrase is translated by a synthetic Ukrainian unit (mostly, derivative adjective or adverb) which on the surface does not show metaphorical nature and it takes etymological analysis to reveal it:

I believe he's half in love with уои (Martin, 2005) - А мені здалося, він у тебе мало не закоханий (Martin, 2017b);

"Stop that, Rhaegal," Dany said in annoyance, giving his head a swat. (Martin, 2000) - Припини, Раегале! - мовила Дані роздратовано і дала йому легенького ляпаса (Martin, 2015a);

They set forth at daybreak to see a man beheaded, twenty in all, and Bran rode among them, nervous with excitement (Martin, 1996) - Вони виїхали на страту ще на світанку - вдвадиятьох, якщо рахувати і схвильованого Брана (Martin, 2015b).

According to the "Etymological Dictionary of the Ukrainian language" (Etymologichnij slovnyuk, 1982-2012), the prefix $\mathbf{3} \boldsymbol{a}$ - goes back to the Proto Slavic prefix $\boldsymbol{z a}$ - related to the Latin $\boldsymbol{a} \boldsymbol{z}$ - meaning "behind", or "on the other side"; the prefix poz- goes back to the Proto Slavic prefix orz- related to the Hittite arhameaning "out", "movement outside"; the prefix $c$ - is a phonetic variant of the prefix 3 - related to the preposition 3 which is used before names of objects "on the surface of which or inside which there is the starting point of an action".

The ideas of "being / moving inside / outside or being on the other side" presuppose the existence of some BOUNDARY, INTERIOR and EXTERIOR which are the minimal structural elements of the CONTAINER image schema.

In quite a number of cases EMOTION-BOUNDARY mappings are substituted with EMOTIONINTERIOR mappings highlighting this structural part (INTERIOR) of the CONTAINER image schema:

Cersei turned on him in green-eyed fury (Martin, 1999) - Серсея обернулася до нього, палаючи пекельним зеленим вогнем у очах (Martin, 2016).

In this case, the preposition $\boldsymbol{y}$ is used in the Ukrainian translation to locate fury in the eyes of the EXPERIENCER. domain:

We also registered cases where the CONTAINER image-schema was substituted by a different source

He woke suddenly, in cold and dread (Martin, 2000) - Сем прокинувся зненацька, охоплений холодом та жахом (Martin, 2015a).

The verb охоплювати / охопити that means "to embrace, capture, cover" expresses an action performed by the EMOTION-AGENT (SUSPICION) on the UNDERGOER (EXPERIENCER). The character of the action prompts the inference that this AGENT is a HUMAN BEING.

We also registered cases where EMOTION-CONTAINER metaphorical mappings were lost: 2015b);

Joffrey was in no mood to listen (Martin, 1996) - Але Джофрі не збирався нічого слухати (Martin, 
The red woman looked down on him in pity (Martin, 1999) -Червона жінка дивилася на нього 3 жсалем (Martin, 2016).

EMOTION-INTERIOR metaphors are mostly reconstructed $(83,90 \%)$ :

I was weak and full of sin, and scorn was more than I deserved (Martin, 2005) - Я був слабкий $i$ сповнений гріха. Я заслуговував ще й на гіршу зневагу (Martin, 2017b);

Only his eyes had spoken; a lord's eyes, cold and grey and full of judgment (Martin, 2000) - Щось проказували тільки його очі - очі можновладия, холодні, сірі, наповнені осудом (Martin, 2015a).

This reconstruction is achieved by using direct synthetic translation equivalents of the English adjectival phrase full of - Ukrainian derivative adjectives с-повнений, на-повнений from повний meaning "full of". The etymology of the prefix $\boldsymbol{c}$ - was explained above; the prefix $\boldsymbol{\mu a}$ - goes back to the Proto Slavic prefix $\boldsymbol{n} \boldsymbol{a}$ - which is related to the Latin prefix nùo- (na) meaning "from", "from inside" (Etymologichnij slovnyuk, 1982-2012).

Just the sight of Samwell Tarly filled him with anger (Martin, 2000) - Самий лише його вигляд розлютив Чета аж до дрижаків (Martin, 2015a).

In this case English analytical phrase to be filled with, verbalising the CONTAINER metaphor, is translated by a Ukrainian derivative verb with the prefix etymologically connected to the idea of a CONTAINER (etymology of the prefix pos- was explained above).

Catelyn said, fretful (Martin, 1999) - ...мовила Кетлін занепокоєно (Martin, 2016).

And here the English synthetic CONTAINER metaphor is reconstructed due to the Ukrainian derivative adverb with the prefix $3 \boldsymbol{3}$ - (etymology see above).

According to our data, the EMOTION-INTERIOR metaphorical model is substituted $(10,30 \%)$ with the metaphorical mappings grounded in the LIVING BEING domain:

A blind rage filled her, a rage at all the world (Martin, 1996) - Ï̈ охопила сліпа лють на весь світ (Martin, 2015b);

A terror as overwhelming as anything Sansa Stark had ever felt filled her suddenly (Martin, 1996) Санса Старк раптом відчула такий напад жаху, якого ще не знала за своє життя (Martin, 2015b).

Ukrainian metaphors are verbalised by the verb охоплювати / охопити and by the noun phrase напад жaxy where the noun жаx ("terror") is the agent of the action expressed by the noun наnad ("attack").

It is worth noticing that the mapping EMOTIONS are LIVING BEINGS is rather productive in Ukrainian and substitutes both EMOTION-BOUNDARY and EMOTION-INTERIOR English mappings.

We also registered the loss $(5,80 \%)$ of the EMOTION-INTERIOR metaphor:

Elmar gave her a scornful look (Martin, 1999) - Елмар кинув на неї нищівний погляд (Martin, 2016);

Don't be a fool," Catelyn said, the anger rising in her (Martin, 1996) - "Та не кажи дурниць", відповіла Кетлін, потроху шаленіючи (Martin, 2015b).

It is worth stressing that in the Ukrainian translations the EMOTION-INTERIOR mapping is substituted or lost less frequently than the EMOTION-BOUNDARY mapping and within the CONTAINER mappings EMOTION-INTERIOR substitutes EMOTION-BOUNDARY but not vice versa.

\section{Conclusions}

The similarities found confirm that a conceptual metaphor reflects the shared biological capacities and also shared physical and social experiences of humans.

English and Ukrainian subjects both conceptualise EMOTIONS in terms of the CONTAINER image schema and both the languages have sufficient linguistic means (analytical and synthetic) to verbalise this metaphorical model. The Ukrainian translations of the English EMOTION as CONTAINER mapping are based on three cognitive operations: reconstruction, substitution and elimination. There are some differences in linguistic instantiations of the EMOTION as CONTAINER mapping in the original and translation stemming from the analytical nature of English and synthetic nature of Ukrainian. If English CONTAINER metaphors are mostly verbalised by prepositional phrases, in other words, syntactically, Ukrainian CONTAINER metaphors are mostly verbalised morphologically, by derivative words with the prefixes, etymologically connected to the idea of a CONTAINER. As for semantic differences, the Ukrainian translator tends to substitute EMOTIONS-BOUNDARIES mappings with EMOTIONS-INTERIORS mappings. It prompts an inference that it is more natural for Ukrainians to imagine EMOTIONAL STATES as SUBSTANCES filling the insides of their bodies than as BOUNDARIES suppressing them from the outside. Another tendency is substituting the CONTAINER as a STATIC PASSIVE ENTITY with some ACTIVE AGENT like a LIVING / HUMAN BEING influencing the EXPERIENCER. The differences might be accounted for by the specificity of the socio-cultural environment underpinning the specificity of the structures of the compared languages and the image of the world of their speakers. 
Anyway, this investigation has just scratched the surface of the problem and its results call for further investigation with a larger body of evidence.

\section{References:}

Anderson, J. R. (1976). Language, memory and thought. Hillsdale, NJ: Erlbaum.

Brown, L. (Ed.) (1993). The new shorter Oxford English dictionary on historical principles (Vols. 1-2). Oxford: Clarendon Press.

Cienki, A. J. (2013). Image schemas and mimetic schemas in cognitive linguistics and gesture studies. Review of Cognitive Linguistics, 11(2), 417-432. https://doi.org/10.1075/rcl.11.2.13cie

Dancygier, B., \& Sweetser, E. (2014). Figurative language. New York: Cambridge University Press.

Dancygier, B. (2016). Figurativeness, conceptual metaphor, and blending. In: Semino E., \& Demjén Z. (eds.). The Routledge Handbook of Metaphor and Language Routledge (pp. 28-41). Routledge. Retrieved 15 July 2017 https://www.routledgehandbooks.com

Etymolohichnyi slovnyk ukrainskoi movy (1982-2012) [Etymological dictionary of the Ukrainian language] (Vols. 1-7). Kyiv, Ukraine: Nauk. Dumka.

Fauconnier, G., \& Turner, M. (2002). The way we think. New York: Basic Books.

Fillmore, Ch. (1982). Frame semantics. In: The Linguistic Society of Korea (ed.), Linguistics in the morning calm (pp. 111-135). Seoul: Hanshin.

Gibbs, R. Jr. (2011). Evaluating conceptual metaphor theory. Discourse processes, 48, 529-562.

Gibbs, R. W., \& Colston, H. (2012). Interpreting metaphor. New York: Cambridge University Press.

Grady, J. (1999). A typology of motivation for conceptual metaphor: correlation vs. resemblance. In: Gibbs, R. Jr., \& Steen G. (Eds.), Metaphor in cognitive linguistics (pp. 79-100). Amsterdam, The Netherlands: John Benjamins.

Hampe, B. (2005). Image schemas in cognitive linguistics: Introduction. In: Hampe, B., \& Grady, J. E., (Eds.). From perception to meaning. Image schemas in cognitive linguistics (pp. 1-14). Berlin: Mouton de Gruyter. https://doi.org/10.1515/9783110197532.0.1

Hardy, C. (1998). Networks of meaning: A bridge between mind and matter. Westport, Connecticut; London: Praeger.

Helmholtz, H. (1925). Treatise on physiological optics. Volume III. The Perceptions of Vision; trans. into English by Optical Society of America. Menasha, Wisconsin: George Banta Publishing Company. Retrieved 15 July 2017 from http//psych.upenn.edu/backuslab/Helmholtz

Johnson, M. (1987). The body in the mind. Chicago: The University of Chicago Press.

Kövecses, Z. (2017). Levels of metaphor. Cognitive linguistics, 28 (2), 209-370. https://doi.org/10.1515/cog-2016-0052

Lakoff, G. (1987). Women, fire, and dangerous things. What categories reveal about the mind. Chicago: The University of Chicago Press.

Lakoff, G. (1990). The invariance hypothesis. Is abstract reason based on image schemas? Cognitive Linguistics, 1(1), $39-74$. https://doi.org/10.1515/cogl.1990.1.1.39

Lakoff, G. (1993). The contemporary theory of metaphor. In: Ortony, A. (ed.), Metaphor and thought (pp. 202-251). New York: Cambridge University Press. https://doi.org/10.1017/CBO9781139173865.013

Lakoff, G., \& Johnson, M. (1980). Metaphors we live by. Chicago: The University of Chicago Press.

Lakoff, G., \& Johnson, M. (1999). Philosophy in the Flesh: The Embodied Mind and Its Challenge to Western Thought. New York: Basic Books.

Lakoff, G., \&Turner, M. (1989). More than cool reason: A field guide to poetic metaphor. Chicago: The University of Chicago Press.

Langacker, R. (1987). Foundations of cognitive grammar. Stanford: Stanford University Press.

Mandler, J. \& Cánovas, C. P. (2014). On defining image schemas. Language and Cognition, 6(4), 510-32.

Martin, Dzh. (2015a). Borva mechiv [A storm of swords] (V. Brodovyj, Trans.). Retrieved 10 September 2018 from http://ice-andfire.in.ua/page/allfiles/

Martin, Dzh. (2015b) Hra prestoliv [A game of throwns]. (V. Brodovyj, Trans.) Retrieved 10 September 2018 from http://ice-andfire.in.ua/page/allfiles/

Martin, Dzh. (2016). Chvara koroliv [A clash of kings] (V. Brodovyj, Trans.). Retrieved 10 September 2018 from http://ice-andfire.in.ua/page/allfiles/

Martin, Dzh. (2017a). Tanok z drakonamy [A dance with dragons] (V. Brodovyj, Trans.). Retrieved 10 September 2018 from http://ice-and-fire.in.ua/page/allfiles/

Martin, Dzh. (2017b). Uchta dlia haivoronnia [A feast for crows] (V. Brodovyj, Trans.). Retrieved 10 September 2018 from http://ice-and-fire.in.ua/page/allfiles/

Martin, G. R. R. (1996). A game of thrones (A song of ice and fire). N.Y.: Bantam Books.

Martin, G. R. R. (1999). A clash of kings (A song of ice and fire, Book 2). N.Y.: Bantam Books.

Martin, G. R. R. (2000). A storm of swords (A song of ice and fire, Book 3). N.Y.: Bantam Books.

Martin, G. R. R. (2011) A dance with dragons (A song of ice and fire, Book 5). N.Y.: Bantam Books.

Martin, G. R. R. A. (2005). A feast for crows (A song of ice and fire, Book 4). N.Y.: Bantam Books.

Martynyuk, A. (2016). The Art of metaphoric political insult within the cognitive framework. In: Chrzanowska-Kluczewska, E., Vorobyova, O. (eds.). Language - literature - the arts: A Cognitive-semiotic interface (pp. 245-261). Frankfurt am Main; Bern: Peter Lang Edition.

Martynyuk, A. (2017). "Now that the magic is gone" or toward cognitive analysis of verbal / co-verbal communication. Kohnitsiia. Komunikatsiia. Dyskurs, 15, 51-72. https://doi.org/10.26565/2218-2926-2017-15-04

Musolff, A. (2016). Political metaphor analysis: Discourse and scenarios. London; New York: Bloomsbury Academic.

Rebrii, O. V. (2012). Suchasni kontseptsiyi tvorchosti u perekladi [Modern concepts of creative activity in translation]: monohrafiya. Kharkiv: KhNU imeni V. N. Karazina Publ.

Ruiz De Mendoza, F., \& Galera, A. (2014). Cognitive modeling. A linguistic perspective. Amsterdam: John Benjamins.

Semino, E. (2008). Metaphor and discourse. Cambridge: Cambridge University Press.

Sullivan, K. (2013). Frames and constructions in metaphoric language. Amsterdam: John Benjamins. 